\title{
THE FABRICATION OF YAM BEAN (PACHYRIZOUS EROSUS) STARCH BASED BIOPLASTICS
}

\author{
H. Judawisastra ${ }^{1 *}$, R.D.R Sitohang ${ }^{1}$, D.I. Taufiq ${ }^{1}$, Mardiyati $^{1}$ \\ ${ }^{1}$ Materials Science and Engineering Research Groups, Faculty of Mechanical and Aerospace \\ Engineering, Institut Teknologi Bandung, Ganesha 10, Bandung 40132, Indonesia
}

(Received: December 2017 / Revised: January 2018 / Accepted: January 2018)

\begin{abstract}
Bioplastics, easily degraded plastics made from renewable biopolymers such as starch and protein, are being studied as possible substitute for synthetic plastics. One of Indonesian natural resources, Jicama (Pachyrizous erosus), also known as yam bean, is believed to have the potential to be made as bioplastics. This study aims to develop starch-based biofilms made from Jicama. The films were fabricated by using the solution casting method, with varying contents of water (67-93 wt\%) and sodium hydroxide (0.3-0.7 g). Examinations were carried out by means of visual inspection, tensile test, scanning electron microscopy and FTIR spectroscopy. A continuous bioplastic film was successfully made with 93 wt.\% water. The addition of water increased film formability. Sodium hydroxide improved the film formability but, also, induced fragility. The highest tensile strength and stiffness of $11.5 \mathrm{MPa}$ and $0.98 \mathrm{GPa}$, respectively were achieved from the film prepared with $93 \mathrm{wt} \%$ water. These values are comparable to LDPE but with a lower ductility.
\end{abstract}

Keywords: Bioplastic; Jicama; Pachyrizous erosus; Starch; Water; Yam bean

\section{INTRODUCTION}

Concerns were raised about the harmful environmental impacts caused by using and disposing non-renewable petroleum-based synthetic plastics. These types of plastics are considered to be non-biodegradable since they need a very long time to be degraded naturally by the environment and will remain exist for centuries. They are commonly used as packaging material for diverse consumer products, such as beverages and foods, and, thus, are used in enormous quantities. It is estimated that, in 2016, the production volume of synthetic plastics increased globally by $3.5 \%$ to 322 megatons. Also, the demand for synthetic plastic will continue to grow rapidly worldwide (Plastic Europe, 2016). Manufacturing of the synthetic plastics require high consumptions of energy and carbon emissions (Campilho, 2016). Therefore, the accumulation of synthetic plastics may cause environmental pollution. Ultimately, this promotes a growing interest in the application of renewable bioplastics as a possible substitute for synthetic plastics. Bioplastics are plastics made from biopolymers, such as starch and protein, which are degraded easily. Starch is considered to be one of the most promising materials to be made as bioplastics since it is sustainable, natural, biodegradable and abundant. From an environmental standpoint, the production starch can reduce the consumption of energy by up to $82 \mathrm{MJ} / \mathrm{kg}$ and $\mathrm{CO}_{2}$ emissions by $6.8 \mathrm{CO}_{2} \mathrm{e} / \mathrm{kg}$ (Campilho, 2016). Another study showed biopolymer enabled savings of $\sim 20 \%$ of energy and $\mathrm{CO}_{2}$

*Corresponding author's email: hermawan.judawisastra@material.itb.ac.id, Tel/Fax: +62-22-2508144 Permalink/DOI: https://doi.org/10.14716/ijtech.v9i2.1129 
emissions (Mohanty et al., 2005).

Starch can be found in most plants such as maize, rice (paddy), wheat, potatoes, cassava, bananas, yams, and sorghum (Carvalho, 2008). Typically, yams grow relatively quickly, i.e. for eight to ten months. One type of yam, i.e. yam bean, is widely available and particularly in Indonesia. Starch has two main polymeric constituents; these are amylose in which the glucose units are linked together in straight chains and amylopectin in which the glucose chains are highly branched (Sam et al., 2016). In starch, the amylose content is particularly important for producing strong film-forming properties, as demonstrated in a study of high-amylose rice and pea starch films (Mehyar \& Han, 2004). Another research group reported that the starch from yam bean contained 23\% amylose (Mélo et al., 2003). This is comparable to the amylose content found in other starch materials that are commonly used for bioplastics, i.e. corn starch $(25 \pm 2 \%)$, and in cassava starch (19 $\pm 2 \%$ ) (Mali et al., 2006). Hence, it is believed that yam bean starch may have the potential to be used as an alternative tropical renewable resource to fabric bioplastic material. For this reason, this study aims to prepare starch-based bioplastic films made from yam bean (Pachyrizous erosus). Further, the addition of sodium hydroxide to yam bean starch bioplastics was studied, also, in this work in an attempt to improve the film-forming properties. This is one of the strategies that has been directed to improve the physical and chemical properties of starchy materials, i.e. rice starch (Rachtanapun et al., 2012) and several cereal starches (Lai et al., 2002).

\section{METHODS}

\subsection{Materials}

The starch, used in this study, was isolated from yam bean tuber. The additive used was a commercially available solid sodium hydroxide. The starch was extracted by using the filtration method.

\subsection{Bioplastic Film Preparation}

The bioplastic films were prepared by using the solution casting method with different concentrations of water from 67 to $93 \mathrm{wt} . \%$ and sodium hydroxides from 0.3 to $0.7 \mathrm{~g}$. The weight percentages of water were calculated with respect to the total weight of dry starch and water. The sample nomenclature was referenced according to the water and $\mathrm{NaOH}$ contents, i.e. $\mathrm{W} x-\mathrm{Na} y$ for a bioplastic film with $\mathrm{x}$ wt.\% water and y $\mathrm{g} \mathrm{NaOH}$. All films were made with a constant amount of $10 \mathrm{~g}$ of dry yam bean starch.

\subsection{Yam Bean Starch Characterization}

The yam bean starch bioplastic, made only with water, was characterized by means of the Fourier Transform Infrared Spectroscopy (FTIR). The FTIR spectra were recorded on a Prestige 21 spectrometer (Shimadzu Corp., Kyoto, Japan) with $4 \mathrm{~cm}^{-1}$ resolution.

\subsection{Bioplastic Films Characterizations}

Formability of the bioplastics was observed by visual inspection. Scanning Electron Microscopy (SEM) was used to investigate the morphology of the produced bioplastic films. Tensile tests were carried out according to ASTM D-882-02 for thin film with a thickness of $0.1 \mathrm{~mm}$. Tensile properties were measured by using a Tensilon RTF-1310 (A\&D Co., Ltd., Tokyo, Japan) equipped with a $1 \mathrm{kN}$ load cell with a $10-\mathrm{cm}$ gage length at a crosshead speed of $5 \mathrm{~mm} / \mathrm{min}$.

\section{RESULTS AND DISCUSSION}

\subsection{Fourier Transform Infrared Spectroscopy (FTIR) Spectroscopy Results}

Figure 1 shows the FTIR results of the Jicama/yam bean starch bioplastic. Many other studies reported functional groups assignment of starch (Arrieta et al., 2011; Kaewtatip \& 
Tanrattanakul, 2008). As expected and summarized in Table 1, the produced bioplastic showed the characteristic peaks of starch, i.e. $\mathrm{O}-\mathrm{H}$ stretching, $\mathrm{C}-\mathrm{H}$ stretching of $\mathrm{CH}_{2}$ and $\mathrm{C}-\mathrm{O}$ stretching. Further, the peak at $1637 \mathrm{~cm}^{-1}$, assigned for $\mathrm{O}-\mathrm{H}$ bending, indicates the presence of water in the sample.

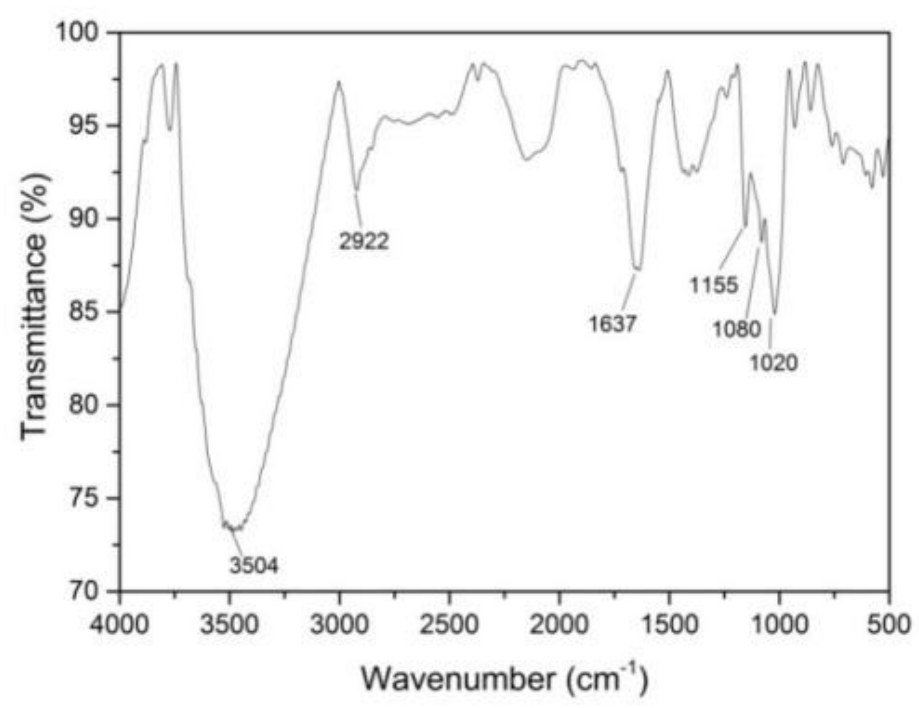

Figure 1 FTIR spectra of Jicama/ yam bean starch bioplastic

Table 1 FTIR assignment of Jicama/ yam bean starch bioplastic

\begin{tabular}{ll}
\hline \multicolumn{1}{c}{ Wavenumber $\left(\mathrm{cm}^{-1}\right)$} & \multicolumn{1}{c}{ Assignment } \\
\hline 3504 (broad) & O-H stretching \\
2922 & C- $-\mathrm{H}$ stretching of $\mathrm{CH}_{2}$ \\
1637 & C-O bending or $\mathrm{OH}$ bending of absorpted water \\
1436 & C- $-\mathrm{H}$ bending of $\mathrm{CH}_{2}$ \\
1375,1413 & $\mathrm{CH}_{2}$ vibration deformation of $\mathrm{CH}_{2} \mathrm{OH}$ \\
1155 & $\mathrm{C}-\mathrm{O}-\mathrm{C}$ antisymmetric stretching \\
$1155,1080,1020$ & C-O stretching \\
$931,858,754$ & C-O-C vibration \\
\hline
\end{tabular}

\subsection{Development of Jicama/ Yam Bean Starch Bioplastics}

This section discusses the effects of the addition of water content and sodium hydroxide on the formability of the Jicama/ yam bean starch bioplastics.

\subsubsection{Effect of water content on the formability of the bioplastics}

Figure 2 (see the first column, in which $0 \mathrm{~g}$ of $\mathrm{NaOH}$ was added) shows that increasing the water content from 67 up to $93 \mathrm{wt} \%$ improves the formability of the resulting bioplastics. For example, please see in Figure 2 that, at 67 wt. $\%$ water, a very discontinuous film was obtained. A continuous film, with no visible cracks, was produced only successfully with 93 wt.\% of water.

The formability of bioplastic is governed by the bonds between the starch granules. This intergranular bonding may be affected by the amount of water added. When a larger amount of water is available, the starch granules will also swell in a greater extent. Therefore, during the gelatinization process, a larger amount of amylose will be released from the granule to the surrounding water (Dumitriu, 2004). Then, when the disrupted hydrogen bonding is restored during retrogradation, the released amyloses form networks between different starch granules. After gelatinization process occurs, secondary bonding between starch and water will be 
restored. Therefore, increasing the water content allows for the formation of more secondary bonding between the starch granules and leads into the development of a more continuous film.

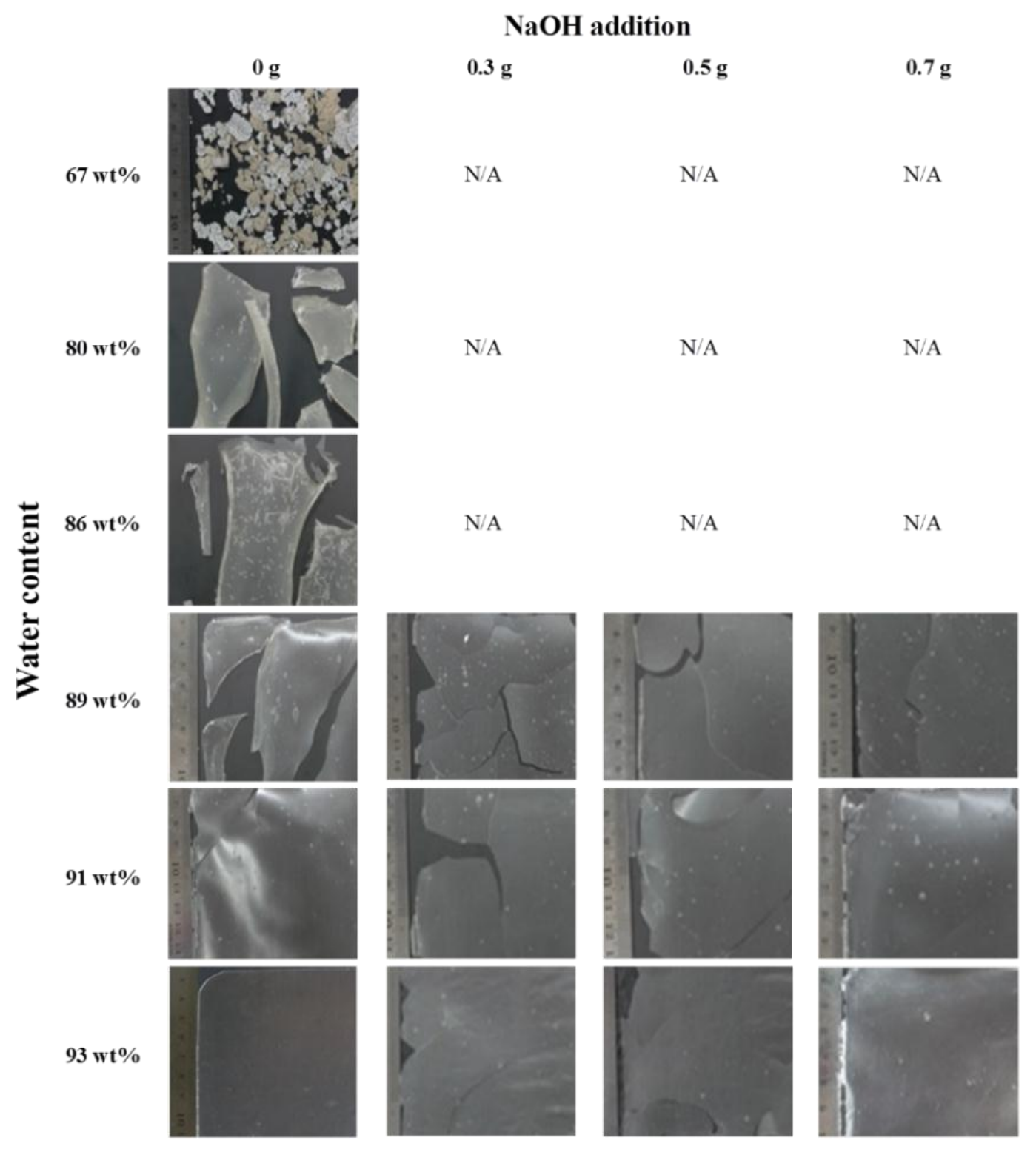

Figure 2 Effect of the addition of water content and sodium hydroxide on the formability of yam bean starch bioplastics

\subsubsection{Effect of the addition of sodium hydroxide on the formability of the bioplastics}

Figure 2, with the water contents increasing from 89 to $93 \mathrm{wt} \%$, shows that increasing the amount of $\mathrm{NaOH}$ up to $0.7 \mathrm{~g}$ generally improves the formability of the resulting bioplastics. $\mathrm{NaOH}$ removes the protein and lipid from the surface of the starch granules (Nadiha et al., 2010). The removal of surface protein and lipid allows the granules to swell more rapidly since the water can access the starch granules more easily. Then, this may then lead to a larger amount of amylose being released from the granule to the surrounding water and, hence, allows for more secondary bonding to be formed between the starch granules.

Please note that the addition of $0.3 \mathrm{~g} \mathrm{NaOH}$ did not improve the formability of the bioplastics and even appeared to produce a rather more discontinuous film when compared to the samples without the addition of any $\mathrm{NaOH}$ (see Figure 2). This may be explained by the presence of 
compounds from the interaction between $\mathrm{NaOH}$, protein and lipid which, probably, may inhibit the interaction between amyloses and, hence, ultimately inhibit the formation of bonding between starch granules during retrogradation. Therefore, when $\mathrm{NaOH}$ is added, there seems to be two opposing mechanisms occurring at the same time, i.e. the formation of an inhibiting compound and the leaching out of amylose. The addition of a smaller amount of $\mathrm{NaOH}$, i.e. 0.3 $\mathrm{g}$, appeared to be insufficient to improve the bioplastic's formability since the formed inhibiting compound might be more dominant in this case. At a higher amount of $\mathrm{NaOH}$ addition, the formability was improved since, although still not as good as that of the initial bioplastic without the addition of any $\mathrm{NaOH}$, the formation of bonding between starch granules might be more dominant.

\subsection{Morphology of Yam Bean Starch}

This section describes the effect of the addition of water content and sodium hydroxide on yam bean starch granules.

\subsubsection{Effect of water content}

Figure 3 shows how the addition of water affects the starch granules. At the lowest water content of $67 \mathrm{wt} . \%$, isolated granules were observed clearly. While at the higher content of water, isolated granules were observed much less and, at $93 \mathrm{wt} \%$ water, even became no longer visible. At the highest content of water, the starch granules appeared to form a continuous phase. In the presence of a higher amount of water, starch granules swell to a greater extent. Therefore, during the gelatinization process, a larger amount of amylose is released from the granule to the surrounding water (Dumitriu, 2004). Then, during retrogradation, the released amyloses, surrounding the granules, form networks between different granules. Therefore, increasing the water content allows ultimately the foirmation of more secondary bonding between the starch granules and, as described earlier in section 3.2.1, leads to the development of a more continuous film.
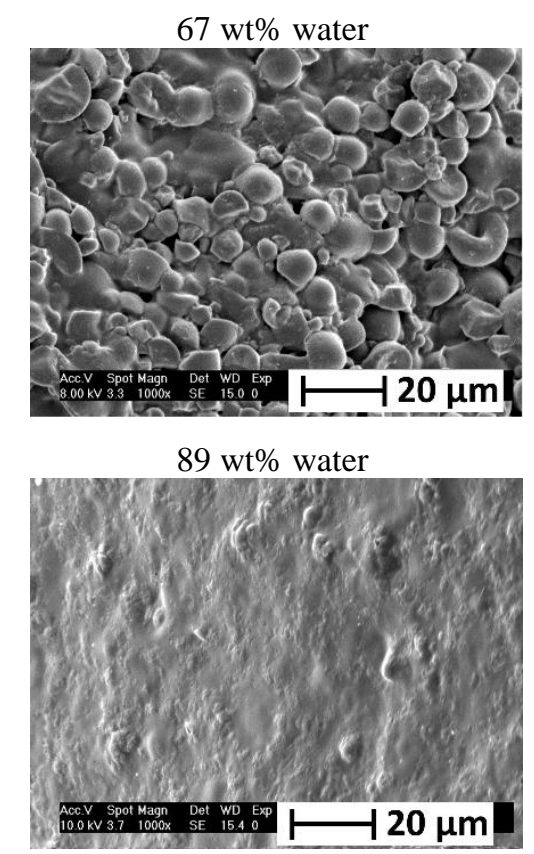

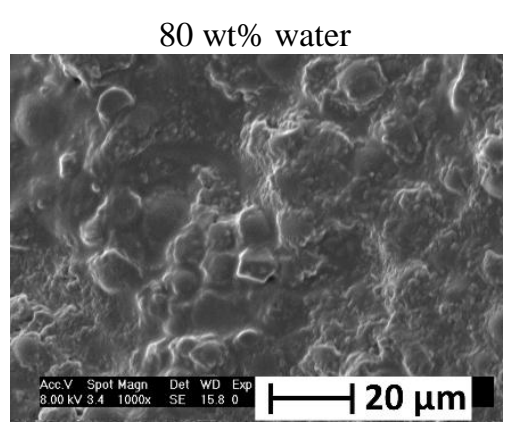

$91 \mathrm{wt} \%$ water

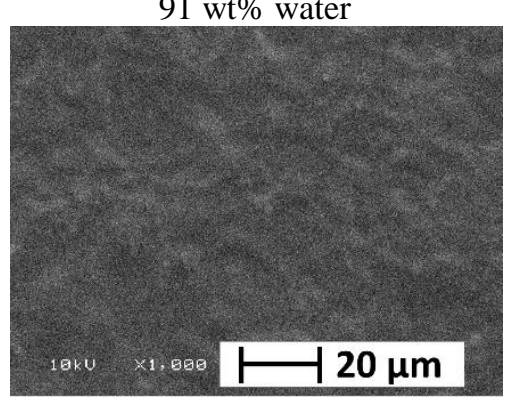

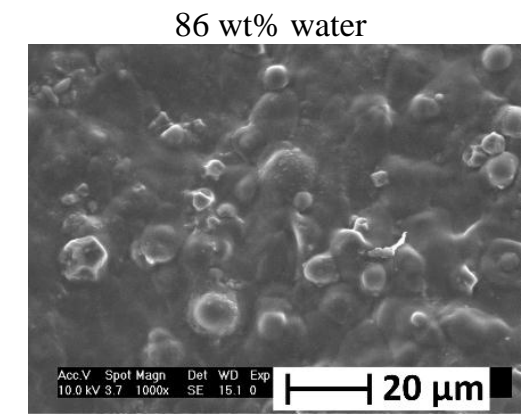

$93 \mathrm{wt} \%$ water

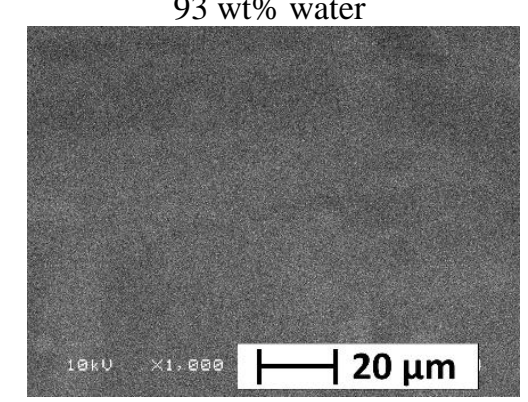

Figure 3 Effect of water content on yam bean starch granules

\subsubsection{Effect of the addition of Sodium Hydroxide}

Figure 4 shows how the addition of $\mathrm{NaOH}$ affects the starch granules of the bioplastics. The addition of $\mathrm{NaOH}$ addition appears to cause cracking on the bioplastics. The cracks, which were 
not observed initially, were clearly visible on the bioplastic with the addition of $0.3 \mathrm{~g} \mathrm{NaOH}$ and became less visible with the addition of $0.7 \mathrm{~g} \mathrm{NaOH}$.
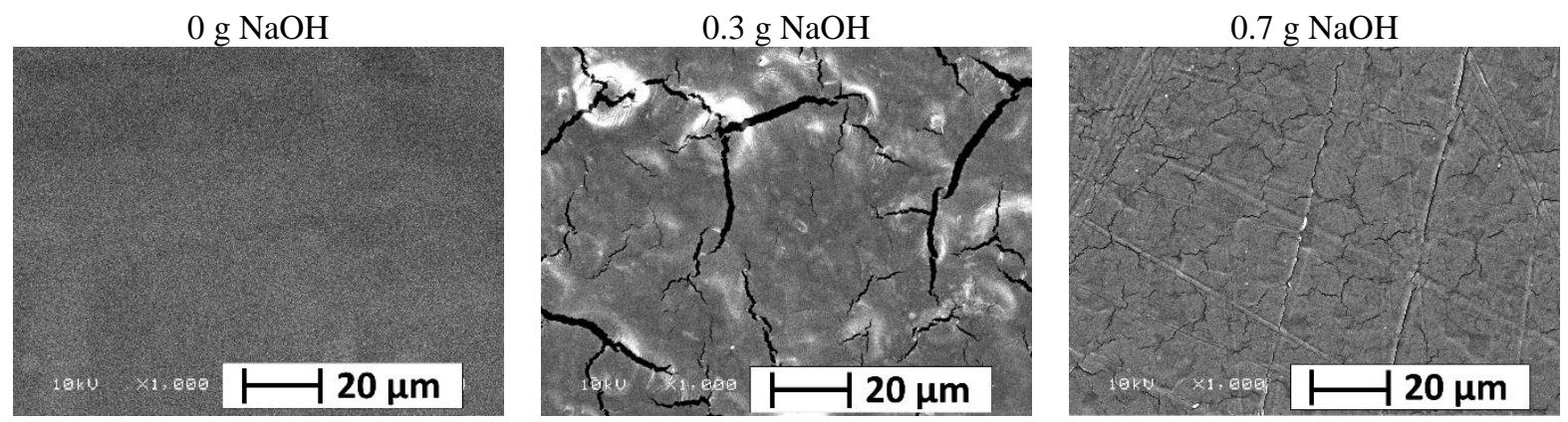

Figure 4 Effect of the addition of $\mathrm{NaOH}$ on yam bean starch granules with $93 \mathrm{wt} . \%$ water

The addition of $0.3 \mathrm{~g} \mathrm{NaOH}$ appeared to produce a discontinuous phase of starch granules when compared to the samples without any $\mathrm{NaOH}$ (see Figure 4). This is consistent with the previous result, shown in Figure 5, in which a more discontinuous film was produced with the addition of $0.3 \mathrm{~g} \mathrm{NaOH}$. With the addition of $0.7 \mathrm{~g} \mathrm{NaOH}$, the cracks became less visible (see Figure 4); this was because the formation of bonding between the starch granules might be more dominant. This agrees well with the result, shown in Figure 2, in which a higher amount of $\mathrm{NaOH}$ improved the formability.

\subsection{Tensile Properties of Jicama Yam Bean Starch Bioplastics}

Figure 5 shows the tensile properties of the resulting bioplastics which had formed continuous films successfully. The highest tensile strength $(11.5 \mathrm{MPa})$ and stiffness $(0.98 \mathrm{GPa})$ was obtained from the bioplastic with $93 \mathrm{wt} . \%$ of water. The produced bioplastics were strong and stiff but brittle. For example, LDPE has a tensile strength in the range from 8.3 to $31.4 \mathrm{MPa}$, stiffness from 0.172 to $0.282 \mathrm{GPa}$ and elongation from 100 to $650 \%$ (Callister and Rethwisch, 2014). When compared to the lower end LDPE, the produced bioplastics had higher tensile strength and modulus but with a much lower ductility. The addition of $0.7 \mathrm{~g} \mathrm{NaOH}$ seems to improve the bioplastic's ductility but at the expense of reduction in the tensile strength and stiffness (see Figure 5). This means that the cracks, as shown in Figure 4 which were developed when $\mathrm{NaOH}$ was added, to the starch granules did not impair the resulting bioplastic's ductility of. However, please note that this improved ductility is still far below that of LDPE (see

Table 2). This is because the highest obtained elongation was only $2.44 \%$. This is rather more comparable to other starch based bioplastics (see Table 2).

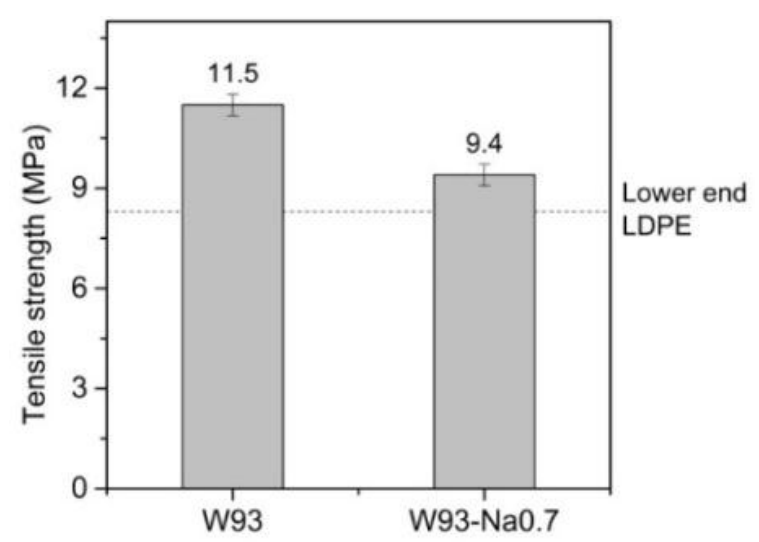

(a)

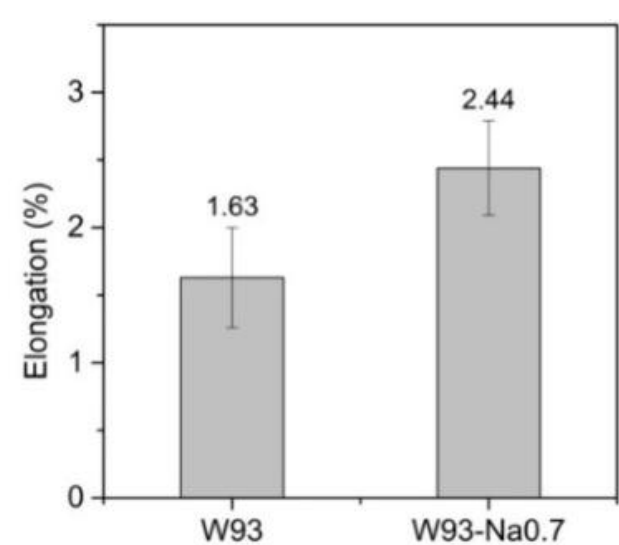

(b) 


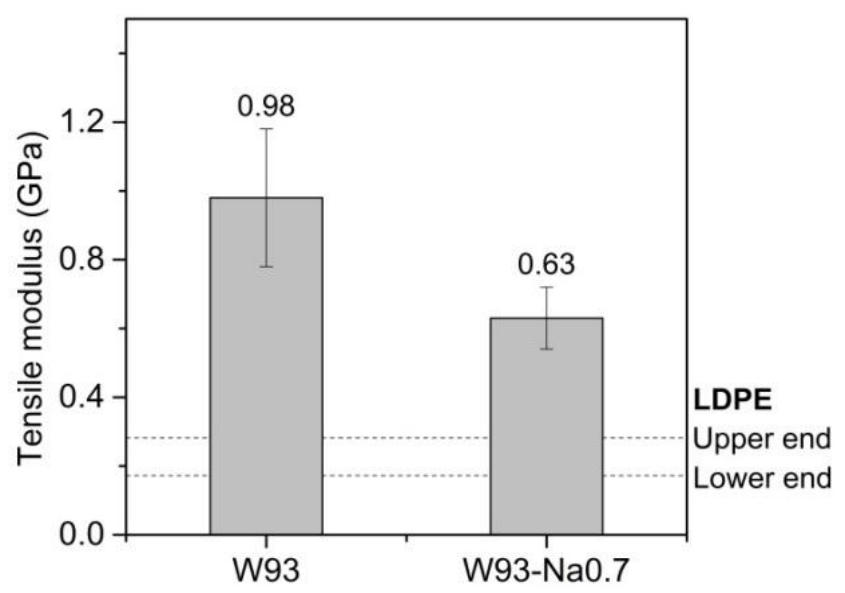

(c)

Figure 5 Tensile properties of yam bean starch bioplastics: (a) tensile strength; (b) elongation; and (c) stiffness. The tensile properties of LDPE were added for comparative purposes (Callister \& Rethwisch, 2014)

Table 2 Tensile properties of other starch-based bioplastics and synthetic plastics

\begin{tabular}{|c|c|c|c|c|}
\hline Material & $\begin{array}{l}\text { Tensile strength } \\
\text { (MPa) }\end{array}$ & $\begin{array}{l}\text { Elongation } \\
(\%)\end{array}$ & $\begin{array}{l}\text { Tensile modulus } \\
\text { (GPa) }\end{array}$ & Ref. \\
\hline Corn starch & $\begin{array}{c}14.22 \pm 0.98 \\
37 \pm 5\end{array}$ & $\begin{array}{c}5.26 \pm 0.83 \\
3 \pm 0.7\end{array}$ & $\begin{array}{c}- \\
1.188 \pm 0.146\end{array}$ & $\begin{array}{l}\text { (Tang et al., 2008) } \\
\text { (Mali et al., 2006) }\end{array}$ \\
\hline Yam starch ${ }^{2}$ & $46 \pm 2$ & $3 \pm 0.7$ & $1.003 \pm 0.050$ & (Mali et al., 2006) \\
\hline Cassava starch & $\begin{array}{l}26 \pm 5 \\
\approx 23\end{array}$ & $\begin{array}{l}6 \pm 0.6 \\
\approx 1.5\end{array}$ & $\begin{array}{l}0.737 \pm 0.108 \\
\quad \approx 2.214\end{array}$ & $\begin{array}{l}\text { (Mali et al., 2006) } \\
\text { (Mali et al., 2005) }\end{array}$ \\
\hline Wheat starch & $14.05 \pm 0.42^{1}$ & $6.08 \pm 0.6^{1}$ & - & (Tang et al., 2008) \\
\hline Potato starch & $14.57 \pm 0.41^{1}$ & $5.47 \pm 0.67^{1}$ & - & (Tang et al., 2008) \\
\hline LDPE & $8.3-31.4$ & $100-650$ & $0.172-0.282$ & $\begin{array}{c}\text { (Callister \& } \\
\text { Rethwisch, 2014) }\end{array}$ \\
\hline
\end{tabular}

\section{CONCLUSION}

A continuous bioplastic film was successfully made with 93 wt.\% water. The addition of water increased the bioplastics' formability. Sodium hydroxide also improved the formability but induced fragility. The highest tensile strength and stiffness of $11.5 \mathrm{MPa}$ and $0.98 \mathrm{GPa}$, respectively, were achieved from the bioplastic film with 93 wt.\% water. While, the highest ductility of $2.44 \%$ was obtained from the bioplastic with $93 \mathrm{wt} . \%$ water and the addition of 0.7 $\mathrm{g} \mathrm{NaOH}$. The obtained strength and stiffness were higher when compared to that of LDPE but with a much lower ductility; this was more comparable to other starch-based bioplastics.

\section{REFERENCES}

Arrieta, A.A., Gañán, P.F., Márquez, S.E., Zuluaga, R., 2011. Electrically Conductive Bioplastics from Cassava Starch. Journal of Brazilian Chemical Society, Volume 22, pp. 1170-1176

Callister, W.D., Rethwisch, D.G., 2014. Materials Science and Engineering: an Introduction, $9^{\text {th }}$ ed. John Wiley \& Sons, Inc., Nuew Jersey, USA

Campilho, R.D.S.G., 2016. Natural Fiber Composites. CRC Press, Boca Raton, FL

Carvalho, A.J.F., 2008. Starch: Major Sources, Properties and Applications as Thermoplastic 
Materials. In: Monomers, Polymers and Composites from Renewable Resources. pp. 321342

Dumitriu, S., 2004. Polysaccharides: Structural Diversity and Functional Versatility, $2^{\text {nd }}$ Edition. CRC Press

Kaewtatip, K., Tanrattanakul, V., 2008. Preparation of Cassava Starch Grafted with Polystyrene by Suspension Polymerization. Carbohydrate Polymers, Volume 73(4), pp. 647-655

Lai, L.N., Karim, A.A., Norziah, M.H., Seow, C.C., 2002. Effects of $\mathrm{Na}_{2} \mathrm{CO}_{3}$ and $\mathrm{NaOH}$ on DSC Thermal Profiles of Selected Native Cereal Starches. Food Chemistry, Volume 78(3), pp. 355-362

Mali, S., Grossmann, M.V.E., García, M.A., Martino, M.N., Zaritzky, N.E., 2006. Effects of Controlled Storage on Thermal, Mechanical and Barrier Properties of Plasticized Films from Different Starch Sources. Journal of Food Engineering, Volume 75(4), pp. 453-460

Mali, S., Sakanaka, L.S., Yamashita, F., Grossmann, M.V.E., 2005. Water Sorption and Mechanical Properties of Cassava Starch Films and their Relation to Plasticizing effect. Carbohydrate Polymers, Volume 60(3), pp. 283-289

Mehyar, G.F., Han, J.H., 2004. Physical and Mechanical Properties of High-amylose Rice and Pea Starch Films as Affected by Relative Humidity and Plasticizer. Journal of Food Science, Volume 69, pp. E449-E454

Mélo, E.A., Stamford, T.L.M., Silva, M.P.C., Krieger, N., Stamford, N.P., 2003. Functional Properties of Yam Bean (Pachyrhizus erosus) Starch. Bioresource Technology, Volume 89(1), pp. 103-106

Mohanty, A.K., Misra, M., Drzal, L.T., 2005. Natural Fibers, Biopolymers, and Biocomposites, $1^{\text {st }}$ ed. Taylor \& Francis, Boca Raton, FL

Nadiha, M.Z.N., Fazilah, A., Bhat, R., Karim, A.A., 2010. Comparative Susceptibilities of Sago, Potato and Corn Starches to Alkali Treatment. Food Chemistry, Volume 121(4), pp. 1053-1059

Plastic Europe, 2016. Plastics - the Facts 2016. Brussels - Belgium

Rachtanapun, P., Simasatitkul, P., Chaiwan, W., Watthanaworasakun, Y., 2012. Effect of Sodium Hydroxide Concentration on Properties of Carboxymethyl Rice Starch. International Food Research Journal, Volume 19(3), pp. 923-931

Sam, S.T., Nuradibah, M.A., Chin, K.M., Hani, N., 2016. Current Application and Challenges on Packaging Industry based on Natural Polymer Blending. In: Olatunji, O. (Ed.), Natural Polymers: Industry Techniques and Applications. Springer International Publishing, Cham, pp. 163-184

Tang, X., Alavi, S., Herald, T.J., 2008. Barrier and Mechanical Properties of Starch-clay Nanocomposite Films. Cereal Chemistry, Volume 85(3), pp. 433-439 